\title{
Sosialisasi Peningkatan Perilaku Hidup Bersih Sehat (PHBS) Sebagai Upaya Memutus Rantai Penularan Virus Corona dalam Situasi Pandemi Covid-19
}

\author{
Eppy Setiyowati ${ }^{{ }^{*}}$, Ni Njoman Juliasih ${ }^{2}$, Umi Hanik ${ }^{3}$, Nyoto ${ }^{4}$, \\ Ira Trio Wahyuni ${ }^{5}$, Singgih ${ }^{6}$
}

1,3. Fakultas Keperawatan dan Kebidanan, Universitas Nahdlatul Ulama Surabaya

2, Institute of Tropical Disease, Universitas Airlangga

4, 5, 6, Staf Keperawatan, Rumah Sakit Bhayangkara Surabaya

4, 5, 6, Mahasiswa Magister Terapan Keperawatan Universitas Nahdlatul Ulama Surabaya

1eppy@unusa.ac.id, ${ }^{2}$ njomanjuliasih@gmail.com, ${ }^{3}$ umihanik@unusa.ac.id,

${ }^{4}$ nyotoo03.mk19@student.unusa.ac.id, 5 iratriooo5.mk19@student.unusa.ac.id,

${ }^{6}$ singgihoo6.mk19@student.unusa.ac.id

\section{Abstrak}

Terjadinya peningkatan jumlah kasus kematian dan penyebaran kasus secara cepat di wilayah lain jadi bukti terjadi transmisi lokal dari virus corona dengan penyakit yang disebut Covid-19. Tujuan kegiatan pengabdian adalah pendidikan kesehatan tentang perilaku hidup bersih dan sehat pada pasien yang berkunjung ke poliklinik RS Bhayangkara Surabaya. Metode pelaksanaan kegiatan sosialisasi dilakukan melalui penyuluhan dengan media elektronik tentang himbauan pemutusan rantai penyebaran covid yaitu cuci tangan dengan sabun atau hand sanitizer, penggunaan masker, jaga jarak 1 meter dan hindari kerumunan lebih dari 5 orang. Kegiatan tersebut dilakukan selama 1 bulan (Juni sampai Juli 2020). Output dari kegiatan pengabdian masyarakat ini adalah media pembelajaran masyarakat dalam bentuk elektronik (video) tentang perilaku hidup bersih dan sehat, artikel yang termuat dalam jurnal nasional pengabdian masyarakat/artikel yang termuat dalam koran.

Kata Kunci: Covid-19, penularan, cuci tangan, masker, handsanitizer

\section{Pendahuluan}

Penyebaran corona virus di Jawa Timur semakin hari semakin meningkat (ALdowyan et al., 2017; Hanik \& Setiyowati, 2020), demikian juga dengan pasien yang masuk ke RS Bhayangkara Surabaya baik sebagai pasien dalam perawatan (PDP) maupun orang dalam pengawasan (ODP). Upaya meningkatkan kewaspadaan penyebaran Covid-19 di RS.Bhayangkara H.S.Samsoeri Mertojoso sebagai berikut: 1) Pemeriksaan suhu tubuh kpd Masyarakat yg memasuki rumah sakit dan memberikan tanda. 2) Melaksanakan Penyemprotan Desinfektan ditempat Pelayanan Publik Polda Jatim dan Semua Unit Pelayanan.

Kesiapsiagaan dalam menghadapi penyebaran Covid 19 telah dilakukan untuk mengantisipasi pemutusan mata rantai penularan Covid 19 sehingga terdapat harapan baru dalam berperilaku hidup bersih dan sehat (Hanik \& Setiyowati, 2020), melalui 3 hal 
tersebut yaitu: 1) masuk ke rumah sakit dengan diperiksa suhu tubuh; 2) penyemprotan dengan desinfektan pada semua ruangan yang diduga menyebabkan perkembangbiakan virus; dan 3) tidak melakukan jabat tangan (social and psysical distancing). Hal tersebut merupakan kondisi dan situasi yang telah dilakukan bersama dengan Biddokkes Polda Jatim dan DPK PPNI Komisariat RS. Bhayangkara H.S. Samsoeri Mertojoso.

Upaya pemutusan mata rantai penyebaran Covid 19 telah dicanangkan melalui 3 hal yaitu1) masuk ke rumah sakit dengan diperiksa suhu tubuh, 2) penyemprotan dengan desinfektan pada semua ruangan yang diduga menyebabkan perkembangbiakan virus, 3) tidak melakukan jabat tangan (social and psysical distancing), namun hal ini belum mampu untuk memberantas penyebaran Virus corana (Goni et al., 2019). Kita ketahui bersama bahwa komunitas sebuah rumah sakit yang utama adalah pasien yang datang berkunjung, sebab pasien tersebut selalu silih berganti setiap hari yang memungkinkan terjadinya pergerakan/ mutasi penyebaran virus Covid 19 semakin lebar. Pergerakan pasien yang selalu keluar masuk sangat perlu dibekali dengan pengetahuan dan pemahaman terhadap penyebaran Virus Corona melalui tindakan promotif dan preventif guna mengantisipasi pemutusan mata rantai penularan (Jazieh et al., 2020)

Permasalahan yang terjadi pada RS. Bhayangkara H.S. Samsoeri Mertojoso adalah : 1) Belum pernah dilakukan edukasi pada pasien dan keluarga di ruang tunggu poliklinik . 2) Belum pernah dilakukan survey pada pasien dan keluarag di ruang tunggu poliklinik tentang perilaku hidup bersih dan sehat dalam memutus mata rantai penularan Covid 19. 3) Penyediaan sarana dan fasilitas untuk cuci tangan dengan sabun bagi pasien di poliklinik masih terbatas.

Berdasarkan permasalahan yang terjadi pada RS Bhayangkara H.S. Samsoeri Mertojoso, perlu dilakukan sosialisasi peningkatan perilaku hidup bersih dan sehat (PHBS) melalui edukasi video seris yang dipasang di tempat/ruang tunggu poliklinik RS. Bhayangkara H.S. Samsoeri Mertojoso. Melalui edukasi vedio series yang berisi tentang 1).cuci tangan dengan sabun atau handsanitizer, 2) memakai masker, 3) jaga jarak (social and psysical distancing), 4) stay at home, 5) tidak mendatangi kerumunan orang dirasa bisa menambah pengetahuan pasien maupun keluarga (Kadioglu et al., 2020).

Beberapa luaran dari solusi yang bisa dikuantitatifkan: 1) Peningkatan pengetahuan terhadap pemutusan mata rantai penularan Covid 19. 2) Perubahan prilaku hidup bersih dan sehat yang dapat diketahui dari hasil survei sebelum dan sesudah dilakukan edukasi vedio seris. 3) Tersedianya fasilitas cuci tangan dengan sabun bagi pasien dan keluarga di poliklinik RS. Bhayangkara H.S. Samsoeri Mertojoso.

\section{Metode Pelaksanaan}

Kegiatan pengabdian masyarakat dilakukan di RS Bhayangkara H.S. Samsoeri Mertojoso berkerjasama dengan Biddokkes Polda Jatim, DPK PPNI Komisariat RS. Bhayangkara H.S. Samsoeri Mertojoso dan Persadia bekerjasama dengan mahasiswa program magister terapan keperawatan Univatsitas Nhdlatul Ulama Surabaya. Sehingga untuk kegiatan dilapangan banyak dilakukan oleh mahasiswa tersebut. 


\section{Tahap Persiapan}

1) Pengurusan ijin dilakukan pengabdian masyarakat yang dilakukan oleh pengusul dengan mahasiswa magister terapan keperawatan ke RS. Bhayangkara H.S Samsoeri Mertojoso

2) Manajemen keperawatan menindaklanjuti dan meneruskan ke Biddokkes Polda Jatim, DPK PPNI Komisariat RS. Bhayangkara H.S. Samsoeri Mertojoso.

3) Pertemuan pengusul dengan manajemen keperawatan RS. Bhayangkara H.S. Samsoeri Mertojoso membahas pembagian fasilitas dan sarana yang disipakan oleh rumah sakit dan pengusul. Fasilitas yang diberikan oleh RS. Bhayangkara H.S. Samsoeri Mertojoso yaitu:

a. Ruangan, kursi tunggu pasien sebagai tempat sosialisasi

b. TV sebagai media sosialisasi

c. Aliran listrik dan kelengkapannya sebagai perangkat melakukan edukasi

d. Kelengkapan Protokol Kesehatan pencegahan Covid 19 (tandon air mengalir, sabun, masker)

e. Mengkoordinasikan danmengkondisikan pasien di poliklinik

\section{Tahap Pelaksanaan}

Kegiatan pengabdian masyarakat ini dilakukan sesuai dengan kesepakatan dengan manajemen keperawatan RS. Bhayangkara H.S. Samsoeri Mertojoso selama 2 bulan yaitu bulan Juni dan Juli 2020.

Sebelum dilakukan edukasi tentang perilaku hidup bersih dan sehat terlebih dahulu dilakukan pengukuran tentang pengetahuan, sikap dan tindakan pasien dalam melakukan pemutusan mata rantai penyebaran covid 19 melalui keusioner. Saat penyebaran kuesioner ini dibantu oleh mahasiswa program magister terapan keperawatan Unusa.

Selanjutkan edukasi tentang perilaku hidup bersih dan sehat dalam memutus rantai penyebaran Covid 19 melalui media TV dengan materi dan video yang telah disipakan dan dirancang oleh pengusul dibantu mahasiswa program magister terapan keperawatan Unusa. Pelaksaan Edukasi melalui media informasi PPT dengan durasi 15 menit dan melelui vidoe selam 20 menit. Hal tersebut diulang dalam kurun waktu 1,5 jam untuk menghindari kebosanan (Whitty et al., 2015).

\section{Tahap Evaluasi}

Tahap Evaluasi Pengukuran pengetahuan, sikap dan tindakan dilakukan ulang dengan kuesioner setelah 1 minggu pelaksaan edukasi dan sekaligus dilakukan pengamatan perilaku pasien terhadap penggunaan fasilitas cuci tangan dan masker yang telah disediakn rumah sakit. 
Vol. 2, No. 2, Mei 2021

ISSN 2721-4834

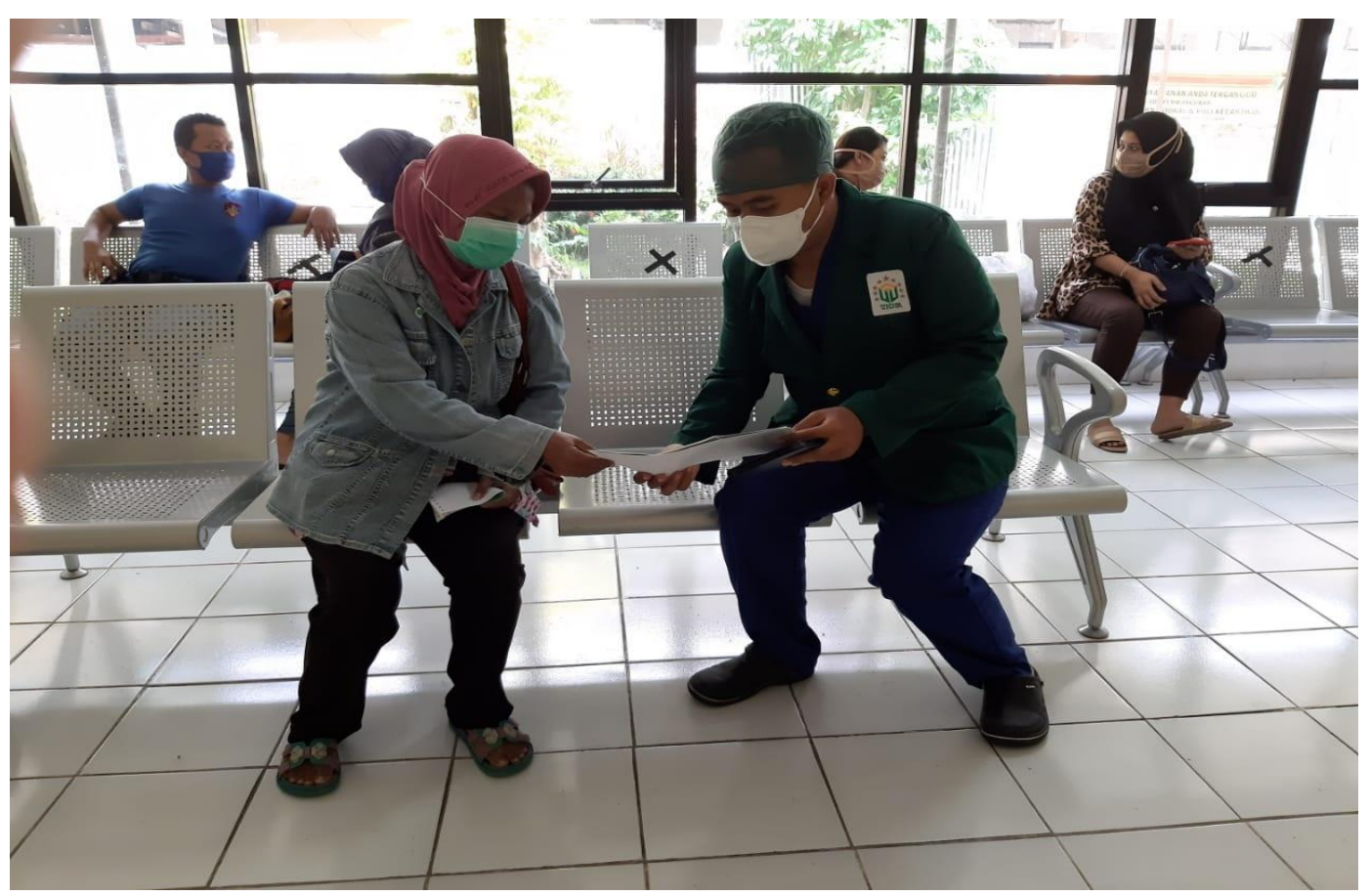

Gambar 1. Kegiatan sosialisasi oleh mahasiswa dengan menggunakan media leafleat kepada pasien yang berada di ruang tunggu

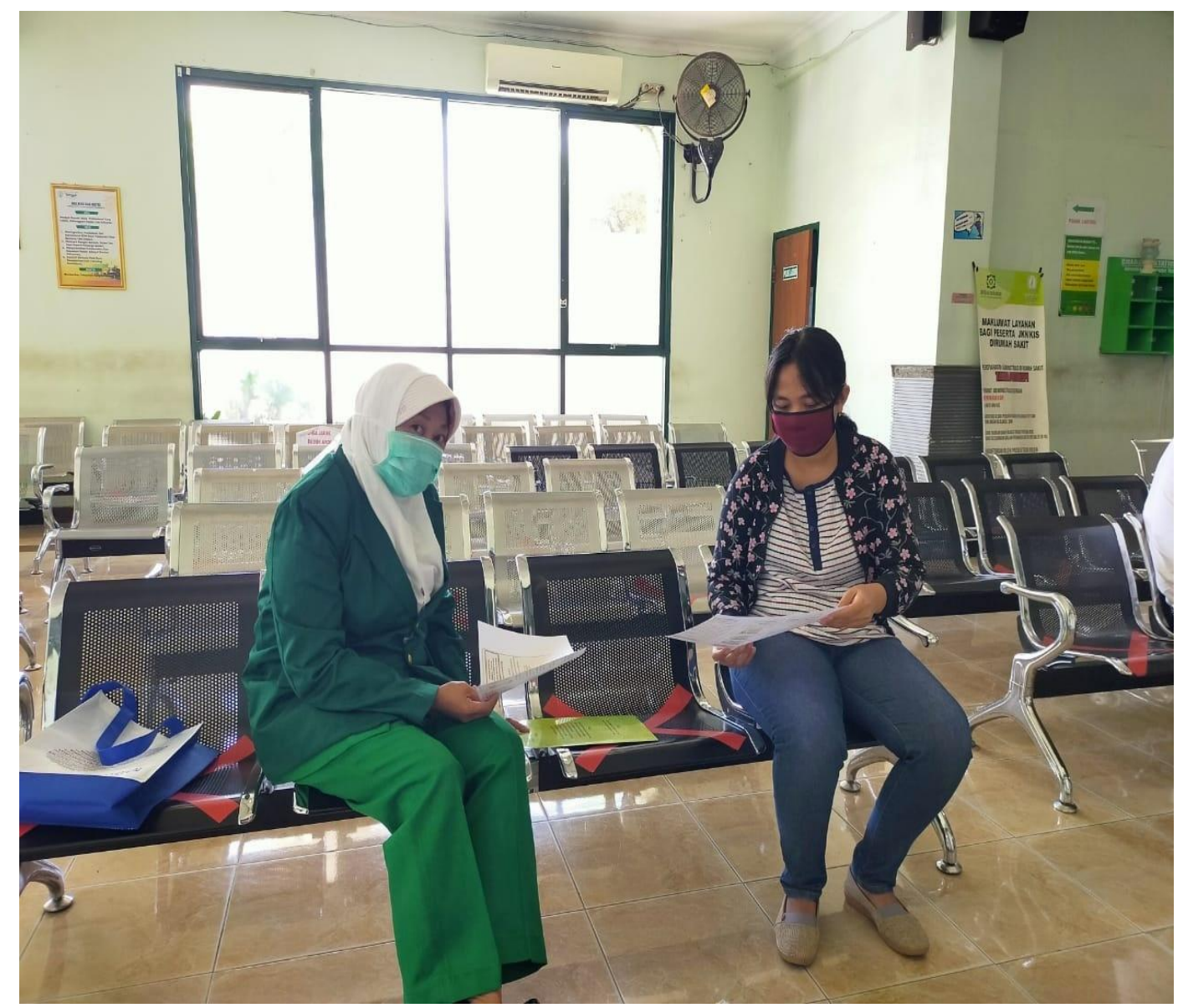

Gambar 2. Kegiatan Sosialisasi perilaku hidup bersih dan sehat melalui buku pintar 


\section{Hasil dan Pembahasan}

Hasil yang dicapai oleh responden adalah adanya peningkatan pengetahuan tentang perilaku hidup bersih dan sehat yaitu melakukan cuci tangan dengan sabun atau hanzaniter, menggunakan masker dan tidak berkemurum atau social distancing. Secara mandiri responden telah melakukan cuci tangan sesuai dengan 6 langkah, setiap hari menggunakan masker dan terbiaya hidup didalam rumah. Studi ini membahas masalah kesehatan utama di Jawa Timur Indonesia.

Hasil ini merupakan hasil yang didapatkan saat evaluasi yang dilakukan dengan crosssectional yang dilakukan pada 250 komunitas lokal di Jawa Timur Indonesia. Hasil pengabdian masyarakat dapat dituliskan dalam table berikut:

Tabel 1. Karakter sosiodemografi Responden $(N=250)$

\begin{tabular}{|c|c|c|c|}
\hline No & & $\mathbf{N}$ & $\%$ \\
\hline 1. & Usia (mean \pm SD), years : $40.49+16.97$ & & \\
\hline \multirow[t]{3}{*}{2.} & Jenis Kelamin & & \\
\hline & Laki - laki & 113 & 45,2 \\
\hline & Perempuan & 117 & 46,8 \\
\hline \multirow[t]{5}{*}{3.} & Tingkat Pendidikan & & \\
\hline & Sekolah Dasar & 25 & 10 \\
\hline & SMP & 55 & 22 \\
\hline & SMA & 123 & 49,2 \\
\hline & Perguruan Tinggi & 47 & 18,8 \\
\hline \multirow[t]{5}{*}{4.} & Work activity & & \\
\hline & Private & 67 & 26,8 \\
\hline & Entrepreneur & 79 & 31,6 \\
\hline & Professional & 54 & 21,6 \\
\hline & PNS/TNI Polri & 50 & 20 \\
\hline
\end{tabular}

Dalam pengabdian ini, mayoritas peserta mengetahui keberadaan kasus yang sedang berlangsung di Jawa Timur Indonesia, yang diperkirakan dengan studi yang dirancang untuk menilai pengetahuan tentang Covid 19, sebagian besar peserta mengetahui tentang wabah Covid 19 yang sedang berlangsung di Timur. Jawa dan banyak peserta mengungkapkan pengetahuan yang rendah tentang masa penularan $(40,8 \%)$, masa 
inkubasi $(35,8 \%)$, dan tidak tersedianya vaksin (25,5\%). Partisipan, 30\% menjawab salah saat ditanya tentang ketersediaan vaksin.

Tabel 2. Pengetahuan, sikap dan Tindakan Prilaku bersih dan sehat $(N=250)$

\begin{tabular}{|c|c|c|}
\hline Score Pengetahuan, sikap dan Tindakan & $\mathbf{N}$ & $\%$ \\
\hline \multicolumn{3}{|l|}{ Pengetahuan: } \\
\hline Baik & 98 & 39,2 \\
\hline Kurang & 152 & 60,8 \\
\hline \multicolumn{3}{|l|}{ Sikap : } \\
\hline Positive & 114 & 57,6 \\
\hline Negative & 136 & 54,4 \\
\hline \multicolumn{3}{|l|}{ Tindakan : } \\
\hline Baik & 87 & 34,8 \\
\hline Buruk & 163 & 65,2 \\
\hline
\end{tabular}

Dibandingkan dengan penelitian ini, hanya 37,6\% yang menjawab tidak ada vaksin. Studi ini menunjukkan tingkat praktik higienis yang tepat di antara peserta. Sembilan puluh empat persen peserta melaporkan mencuci tangan secara teratur, dan lebih dari 90\% melaporkan menggunakan tindakan etiket pernapasan dengan peningkatan yang signifikan dalam kesadaran higienis setelah program internasional. Dalam sebuah studi yang bertujuan untuk menguji knowledge, attitude and practice (KAP) terhadap penggunaan sungkup di Jawa Timur Indonesia, di mana sungkup dan respirator dianggap sebagai pendekatan yang efektif untuk mencegah infeksi saluran pernapasan, sebagian besar peserta menggambarkan sungkup / saluran pernapasan sebagai satu-satunya dan metode perlindungan terbaik yang tersedia untuk melindungi dari penularan Covid 19.

Dalam kegiatan ini kami mengenai perawatan diri dan tindakan pengamanan selama pandemi, mayoritas setuju bahwa memakai masker wajah sangat penting (34,8\%). Sebuah studi terhadap KAP partisipan profesional terkait Covid 19 menunjukkan bahwa 75, $3 \%$ partisipan profesional tidak yakin bahwa masker bedah standar akan melindungi mereka, 31,9\% tidak percaya bahwa mencuci tangan dengan air dan sabun dapat melindungi mereka, dan 57,4\% ragu-ragu. Temuan ini menunjukkan bahwa ada kekurangan pengetahuan yang signifikan di antara peserta profesional bahkan pada tingkat tindakan perlindungan dan pengendalian infeksi dasar (Viana et al., 2020; Huang et al., 2020). Untuk memperbaiki kurangnya pengetahuan ini, diperlukan lebih banyak pendidikan dan aplikasi praktis (Garssen \& Kraneveld, 2020; ALdowyan et al., 2017; Zhong et al., 2020). Hasil ini berkorelasi dengan penelitian ini bahwa ada kesenjangan pengetahuan antar peserta (Srichan et al., 2020). 
Oleh karena itu, butuh lebih banyak pendidikan dan kesadaran tanpa menimbulkan kepanikan di kalangan publik (Goni et al., 2019; Li et al., 2020). Selain itu, penetapan program profesional dan pekerjaan di antara peserta sangat peting untuk meningkatkan KAP mereka (Jazieh et al., 2020; Tanaka et al., 2020). Intervensi pendidikan berkala menggunakan metode yang disesuaikan secara lokal dapat berkontribusi untuk mencegah praktik yang buruk dan kurangnya pengetahuan (Alhamlan et al., 2017; Leffler, 2020). Pendekatan bertahap harus dilakukan untuk meningkatkan KAP peserta dengan melaksanakan program intervensi yang terstruktur dengan baik (Modjarrad et al., 2016; Koyama et al., 2020).

\section{Kesimpulan}

Sosialisasi melalui program health education mampu meningkatkan pengetahuan masyarakat terhadap pemutusan mata rantai Covid 19. Health education tersebut dilakukan melalui video dan leaflet yang direplay setiap 15 menit, dengan demikian para pengunjung di poliklinik RS Bhayangkara memahami pelaksanaan cuci tangan melalui tehnik 6 langkah.

\section{Ucapan Terimakasih}

Kegiatan pengabdian masyarakat ini dibiayai oleh Lembaga Penelitian dan Pengabdian Masyarakat Universitas Nahdlatul Ulama Surabaya dengan nomor kontrak: 438/UNUSA/Adm-LPPM/V/2020.

\section{Referensi}

ALdowyan, N., Abdallah, A. S., \& El-Gharabawy, R. (2017). Knowledge, Attitude and Practice (KAP) Study about Middle East Respiratory Syndrome Coronavirus (MERS-CoV) among Population in Saudi Arabia. International Archives of Medicine, 10, 1-12. https://doi.org/10.3823/2524

Alhamlan, F. S., Majumder, M. S., Brownstein, J. S., Hawkins, J., Al-Abdely, H. M., Alzahrani, A., Obaid, D. A., Al-Ahdal, M. N., \& BinSaeed, A. (2017). Case characteristics among Middle East respiratory syndrome coronavirus outbreak and non-outbreak cases in Saudi Arabia from 2012 to 2015. BMJ Open, 7(1), 1-7. https://doi.org/10.1136/bmjopen-2016-011865

Goni, M. D., Hasan, H., Naing, N. N., Wan-Arfah, N., Deris, Z. Z., Arifin, W. N., \& Baaba, A. A. (2019). Assessment of knowledge, attitude and practice towards prevention of respiratory tract infections among hajj and umrah pilgrims from Malaysia in 2018. International Journal of Environmental Research and Public Health, 16(22), 111. https://doi.org/10.3390/ijerph16224569

Hanik, Umi. Setiyowati, E. (2020). Management Education Healthy Life Behavior Towards Changes In Perception And Knowledge Of COVID Transmission 19. The International Conference on Ummah: Digital Innovation, Humanities and Economy 2020 or Known as ICU: DIHEC 2020. ICU: DIHEC 2020, 1(1), 15.

Huang, Y., Yang, L., Dai, H., Tian, F., \& Chen, K. (2020). Epidemic situation and forecasting of COVID-19 in and outside China. Bulletin of the World Health Organization, December 2019, 2-4. https://www.who.int/bulletin/online_first/20-255158.pdf 
Jazieh, A.-R., Alenazi, T. H., Alhejazi, A., Al Safi, F., \& Al Olayan, A. (2020). Outcome of Oncology Patients Infected With Coronavirus. JCO Global Oncology, 6, 471-475. https://doi.org/10.1200/go.20.00064

Kadioglu, O., Saeed, M., Greten, H. J., \& Efferth, T. (2020). Identification of novel compounds against three targets of SARS CoV- 2 coronavirus by combined virtual screening and supervised machine learning.

Koyama, T., Platt, D. E., \& Parida, L. (2020). Variant analysis of COVID-19 genomes. Bulletin of the World Health Organization, February. https://www.researchgate.net/publication/339461351_Variant_analysis_of_COVID -19_genomes

Leffler, C. T. (2020). Country-wide Mortality from the Novel Coronavirus ( COVID-19) Pandemic and Notes Regarding Mask Usage by the Public Final Country-wide Mortality from the Novel Coronavirus ( COVID-19) Pandemic and Notes Regarding Mask Usage by the Public . April. https://doi.org/10.13140/RG.2.2.36006.27200

Li, J., Yuan, P., Heffernan, J., Zheng, T., Ogden, N., \& Sander, B. (2020). Observation Wards and Control of the Transmission of COVID-19 in Wuhan Abstract : April.

Modjarrad, K., Moorthy, V. S., Millett, P., Gsell, P. S., Roth, C., \& Kieny, M. P. (2016). Developing Global Norms for Sharing Data and Results during Public Health Emergencies. PLoS Medicine, 13(1), 1-5. https://doi.org/10.1371/journal.pmed.1001935

Srichan, P., Apidechkul, T., Tamornpark, R., Yeemard, F., Khunthason, S., Kitchanapaiboon, S., Wongnuch, P., Wongphaet, A., \& Upala, P. (2020). Knowledge, Attitude and Preparedness to Respond to the 2019 Novel Coronavirus (COVID-19) Among the Bordered Population of Northern Thailand in the Early Period of the Outbreak: A Cross-Sectional Study. SSRN Electronic Journal. https://doi.org/10.2139/ssrn.3546046

Tanaka, S., Ueno, R., Gilmour, S., Tanoue, Y., Nomura, S., Miyata, H., Yoneoka, D., Group, P., Zealand, N., Care, I., Science, C., \& Memorial, M. (2020). Impact of travel restrictions on importation of novel coronavirus infection : An effective distance approach. March, 3-6.

Viana, P. V. de S., Paiva, N. S., Villela, D. A. M., Bastos, L. S., Bierrenbach, A. L. de S., \& Basta, P. C. (2020). Factors associated with death in patients with tuberculosis in Brazil: survival analysis with competitive risks. PloS One, Oktober, 1-16. https://doi.org/10.21203/rs.2.13108/v1

Whitty, C. J. M., Mundel, T., Farrar, J., Heymann, D. L., Davies, S. C., \& Walport, M. J. (2015). Providing incentives to share data early in health emergencies: The role of journal editors. The Lancet, 386(10006), 1797-1798. https://doi.org/10.1016/So1406736(15)00758-8

Zhong, B.-L., Luo, W., Li, H.-M., Zhang, Q.-Q., Liu, X.-G., Li, W.-T., \& Li, Y. (2020). Knowledge, attitudes, and practices towards COVID-19 among Chinese residents during the rapid rise period of the COVID-19 outbreak: a quick online cross-sectional survey. International Journal of Biological Sciences, 16(10), 17451752. https://doi.org/10.7150/ijbs.45221 